\title{
Tillage Systems and Fertilization for Increase of Yam's Local Tuber (Dioscorea esculenta) on Farming System at Moluccas
}

\author{
Edwen D. Waas ${ }^{+}$, Sheny S. Kaihatu ${ }^{+}$ \\ Researchers of Moluccas Assessment Institute for Agriculture Technology \\ Chr. Soplanit Street, Rumah Tiga-Ambon
}

Marthen P. Sirappa ${ }^{+}$(Corresponding Author)

Researcher of West Sulawesi Assessment Institute for Agriculture Technology

Complex of Government Office West Sulawesi Provence, Abdul Malik Pattana Endeng Street, Mamuju 97512, Email: mpsirappa@gmail.com

+ Main Contributor

Received: June 19, $2020 \quad$ Accepted: Sep. 11, $2020 \quad$ Published: Sep. 29, 2020

doi:10.5296/jas.v8i4.17760ＵRL: https://doi.org/10.5296/jas.v8i4.17760

\begin{abstract}
A field research was conducted at Makariki Experimental Farm, Moluccas Assessment Institutes for Agricultural Technology, Central Moluccas. The study aims to know the effect of tillage systems and fertilization for increase of growth and yield of yam's local tuber (Dioscorea esculenta). Experiments using split plot design with 20 treatments and three replications. The main plot were tillage system consisted of four tillage systems, ie: (A1) Minimum Tillage + Single Mound/"Kuming"; (A2) Minimum Tillage + Lenghtwise Mound/"Guludan"; (A3) Intensive Tillage + Single Mound, and (A4) Intensive Tillage + Lenghtwise Mound, sub plots were fertilization, consisting of (B0) Without fertilizeration; (B1) Complete NPK Fertilization (135 kg N +135 kg $\mathrm{P}_{2} \mathrm{O}_{5}+90 \mathrm{~kg} \mathrm{~K} 2 \mathrm{O} / \mathrm{ha}$ ), (B2) $\mathrm{NP}$ Fertilization (135 kg N + $90 \mathrm{~kg} \mathrm{P}_{2} \mathrm{O}_{5} / \mathrm{ha}$ ), (B3) NK Fertilization (135 kg N + $135 \mathrm{~kg} \mathrm{~K} 2 \mathrm{O} / \mathrm{ha}$ ), and (B4) PK Fertilization (90 kg $\left.\mathrm{P}_{2} \mathrm{O}_{5}+135 \mathrm{~kg} \mathrm{~K} 20 / \mathrm{ha}\right)$. Sub plot size $4 \mathrm{~m}$ x $3 \mathrm{~m}$ with spacing of $100 \mathrm{~cm} \times 75 \mathrm{~cm}$. Source of fertilizer N, P and K in a row came from Urea, TSP, and $\mathrm{KCl}$. Fertilizer $\mathrm{N}$ and $\mathrm{K}$ are given three times, i.e. the one third dose given at age 10 dap (days after planting), one third dose at age 30 dap and the rest one third dose at age 60 dap, whereas the $\mathrm{P}$ fertilizer entirely given at age 10 dap. The results showed that the tillage system and fertilization in single influence on growth, yield components and yield per hectare
\end{abstract}


of yam's local tuber, but both are no significant interactions. Intensive tillage system, followed by creating lenghtwise mound influence the growth and yield components as well as providing the highest yield of yam's local tuber (19.97 t/ha). Complete NPK fertilization (135 $\mathrm{kg} \mathrm{N}+135 \mathrm{~kg} \mathrm{P}_{2} \mathrm{O}_{5}+90 \mathrm{~kg} \mathrm{~K} 2 \mathrm{O} / \mathrm{ha}$ ) also provides a real influence on the growth and yield components as well as providing the highest yield of yam's local tuber $(21.86 \mathrm{t} / \mathrm{ha})$ and not significantly different compared to the $\mathrm{NK}$ fertilization $(135 \mathrm{~kg} \mathrm{~N}+135 \mathrm{~kg} \mathrm{~K} 2 \mathrm{O} / \mathrm{ha}$ ) which consist of $19.58 \mathrm{t} / \mathrm{ha}$.

Keywords: Tillage system, fertilization, yam's local tuber, single mound, lengthwise mound

\section{Introduction}

Preservation of germplasm as a genetic source will determine the success of the food development program. The desirable food sufficiency will depend on the diversity of germplasm possessed because in fact the superior varieties, which have been, are, and will be assembled are a collection of specific genetic diversity expressed in the desired superior traits (Sianipar 2015).

Tubers plant (cassava, sweet potato, yams and cocoyams) as a genetic source of non-rice carbohydrates is a traditional food crop for the people of Moluccas. Cassava and sweet potato are classified as the main tubers, while yams and cocoyams are classified as rare minor tubers, because this species is almost extinct and only developed in a small number of local farmers. Based on the characterization of agro-ecological zone (AEZ), the potential of land that can be developed for food crops in Moluccas (excluding North Moluccas) in terms of altitude (0 $750 \mathrm{~m}$ above sea level/asl) with a slope $(0-8 \%)$ there are 425,998.4 ha (Irianto et al. 1998; Rieuwpassa et al. 1999) and only 30,438 ha were used, so the potential for development was $395,550.4$ ha. In addition to potential untapped land, there are also a number of lands which have not been used optimally or are left unused. Thus the development of traditional food crops (tubers and corn) in Moluccas in the future still has considerable opportunities.

According to Musa et al. (2011), yam is an annual tuber and monocot plant. It belongs to the genus Dioscorea and the family Dioscoreacea. The food plant comprises of 600 species out of which ten species produces edible tubers and only six are cultivated in Africa. As a root crop, the place of yam in the diet of the people in West Africa and in Nigeria in particular cannot be overemphasized. Akinola et al. (2019) reported that yam holds important position as a food and industrial crop in the Nigerian economy. Babaleye (2003) noted that yam contributes more than 200 dietary calories per capita daily for more than 150 million people in West Africa while serving as an important source of income to the people.

The potential minor tubers for developed as alternative food crops are yams (Dioscorea alata- Coconut Sweet Potato/Uwi and Dioscorea esculenta/Gembili), and Cocoyams (Xanthosoma sagittifolium/Calladium and Colocasia esculenta/Taro). This cassava is spread throughout Moluccas (including North Moluccas) both the Central Moluccas, Southeast Moluccas (including West Southeast Moluccas) and North Moluccas development areas. The results of the Pattimura University, Faculty of Agriculture against other edible cassava varieties show that in the Central Moluccas development area there were at least 70 varieties 
of Yams (Dioscorea spp) and 7 varieties of Cocoyams (Xanthosoma sagittifolium and Colocasia esculenta), in the development area of Southeast Moluccas (including West Southeast Moluccas) has at least 38 varieties of Yams and 16 varieties of Cocoyams, while in the development area of North Moluccas it has at least 6 varieties of Yams and 3 varieties of Cocoyams (Lalopua et al. 1989). Considering that cassava yields are in the soil, the cultivation technology component that needs serious attention is the land preparation technology component (including soil processing) and fertilization.

On Moluccas, land preparation for food crops carried out by local farmers is known as SBP (slash-burn-planting), that is shrubs/forests are slash, left to dry then burned, burning results cleared, immediately planted without tillage. Especially tuber crops are local tillage, that is the soil is boiled and raised to form cones or known as "kuming"/hill. The distance between the ears varies depending on the soil structure and size of the ear. Land with heavy structure with small size and smaller distance, and vice versa for soil with light structure. The kuming system is also known in Nigeria.

Reseach result of Kang \& Wilson (1981), white Guinea yam (Dioscorea rotundata) which were planted with a system of mound gave higher yields than without mounding. According to Mahama (1995), the main basis of land preparation techniques in the form of a mound in an effort to prevent erosion and excessive surface runoff at harvest (breaking the tuber) is the coefficient of porosity and the oblique angle of the dune section. Research results in Nigeria, showed that the wider the base diameter and the height of the mound the higher the tuber yield obtained (Kang \& Wilson 1981). Whereas Mahama's research (1995) in Bimbia (Ghana) shows that mound height at $1617 \%$ water content is $70 \mathrm{~cm}$ with an inclined angle on the inner mound of 480. Research on the effect of fertilization on growth and production of yams is still limited. Research by Nwingi (1983) with Dioscorea rotundata shows that fertilization yields higher tuber yields and is significantly different than without fertilization, whereas between fertilization treatments do not provide significant differences in yield. Lalopua et al. (1989) suggested that the yams plant (Dioscorea spp) is responsive to nitrogen and potassium, also requiring an adequate supply of phosphorus. Unpatti's Faculty of Agriculture research

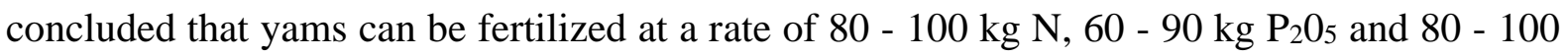
$\mathrm{kg} \mathrm{K} 20$ per hectare (Lalopua et al. 1989). Thus the improvement of cultivation technology, especially the soil conservation tillage and fertilization technology needs serious attention.

According to Heyne (1987), Dioscorea has long been known and used in human life. The users of this plant are also wide ranging from developing countries to developed countries, and the forms of use also vary. Two prominent forms of use of Dioscorea are as food and medicine. Dioscorea research for medicine and foodstuffs has also been carried out by scientists from Japan, China, Korea, India, Indonesia, Africa, France and England. This shows how great the potential of Dioscorea (Eprilianti 2000).

Research on the technology component of yam's local tuber (Dioscorea esculenta) on dry land agroecosystem is expected to be a specific technology that can be applied, beneficial and accepted by farmers and environmentally friendly.

This study aims to know the effect of tillage system and fertilization for increase the growth 
and yield of yam's local tuber (Dioscorea esculenta) at Moluccas.

\section{Methodology}

The study was conducted at the Makariki Experimental Garden, Moluccas for Assessment Institute Agricultural Technology, Central Moluccas. The study used a Split Plot Design with three replications. The treatment of the tillage system is placed as a Main Plot consisting of four types, namely: (A1) Minimum tillage + Single Mound/Kuming; (A2) Minimum tillage + Lenghtwise Mound/Guludan; (A3) Intensive tillage + Single Mound; and (A4) Intensive tillage + Lenghtwise Mound. Whereas Fertilization is placed as Plots, consisting of (B0)

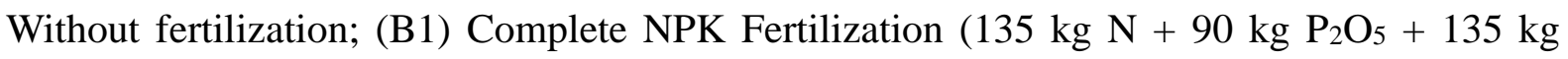
$\mathrm{K}_{2} \mathrm{O}$ per ha); (B2) NP Fertilization (135 kg N + 90 kg $\mathrm{P}_{2} \mathrm{O}_{5}$ per ha); (B3) NK Fertilization (135 kg N + $135 \mathrm{~kg} \mathrm{~K} 2 \mathrm{O}$ per ha); and (B4) PK Fertilization (90 kg $\mathrm{P}_{2} \mathrm{O}_{5}+135 \mathrm{~kg} \mathrm{~K} 20$ per ha). Minimum tillage, i.e. cultivated only on the rows of plants by hoeing twice, whereas intensive tillage is namely whole tillage (plow once and harrow twice). "Kuming" that is cone-shaped buried soil (single mound), whereas "guludan" i.e. land-shaped buried soil (lenghthwise mound).

Plot size $4 \mathrm{~m} \times 3 \mathrm{~m}$ with a spacing of $100 \mathrm{~cm} \times 75 \mathrm{~cm}$. Sources of N, P, and K fertilizers are from Urea, TSP, and $\mathrm{KCl}$, respectively. Fertilizer $\mathrm{N}$ and $\mathrm{K}$ are given three times, namely $1 / 3$ of the dose given at the age of 10 days after planting (dap), 1/3 dose at the age of 30 dap and the remaining $1 / 3$ dose at the age of 60 dap, while the $\mathrm{P}$ fertilizer entirely given at the age of 10 dap.

Observed variables included plant height at harvest, tuber number and length, percentage of small tuber, tuber diameter, tuber weight per plant, and tuber yield per hectare (conversion of $6 \mathrm{~m}^{2}$ harvest plots).

Data were analyzed statistically, consisting of analysis of variance (F-test) to determine the effect of treatment and t-test (Duncan Multiple Range Test) to see the difference in influence between treatments that were examined using the procedures of Gomez \& Gomez (1995).

\section{Results and Discussion}

\section{Growth of Yam's Local Tuber (Gembili)}

The results of the statistical analysis (Table 1) show that the tillage system and fertilization had a significant single effect on plant growth and the yield of yam's local tuber, while the interaction not significant effect. Furthermore, Table 1 shows that the intensive tillage, followed by making single mound and lengthwise mound giving higher length of yam's local tuber plants compared to minimum tillage. 
Table 1. Tillage System and Fertilization for Increase Plant Height of Yam's Local Tuber at Harvest at Makariki Experimental Garden, Central Moluccas

Main Plot = Tillage System

A1 $=$ MT + Single Mound $/$ Kuming

A2 $=$ MT + Lenghtwise Mound/Guludan

A3 $=$ IT + Single Mound/Kuming

A4 = IT + Lenghtwise Mound/Guludan

Average of Main Plot (MP)

\section{Sub Plot = Fertilization}

B0 $=$ Without Fertilization

B1 = Complete NPK Fertilization

B2 $=$ NP Fertilization

B3 $=$ NK Fertilization

B4 = PK Fertilization

Average of Sub Plot (SP)

Interaction MP x SP

CF (\%) MP

SP
$228.00 \mathrm{c}$

$235.92 \mathrm{bc}$

$240.58 \mathrm{~b}$

$300.17 \mathrm{a}$

251.17

$278.54 \mathrm{a}$

$259.17 \mathrm{~b}$

$261.88 \mathrm{~b}$

$258.65 \mathrm{~b}$

251.17

ns

7.14

13.12

Remarks:- The average number of lines followed by the same letter is not significantly different from accuracy level of 95\% DMRT test.

- ns : not significant

- MT = Minimum Tillage; IT = Intensive Tillage

- N=Nitrogen; $\mathrm{P}=$ Phosphate; $\mathrm{K}=$ Potassium

This is due to minimum tillage, that is without land if directly made "kuming"/single mound and "guludan"/lengthwise mound is less loose causing poor soil aeration. Whereas if the soil is intensive tillage (plow once and harrow twice), the soil becomes loose and the soil aeration becomes good. This situation causes the growth and development of roots better, so that the absorption of nutrients through the process of interception of roots, mass flow, and diffusion processes run smoothly and also accelerate the process of translocation of nutrients from roots to leaves causing vegetative growth faster and plants grow taller. This is consistent with the results of Alfon's (2002) research, the more intensive the tillage, the lower the weight of the soil content, because the soil is loose and the number of macro pores increases so that the permeability rate increases (Nurida et al. 1999; Mastur 1994).

Fertilization also has a significant effect on vegetative growth (length of yam's local tuber plants) as in Table 1. Furthermore, Table 1 shows that without the application of plant fertilizers the growth was significantly lower than that of fertilizer application. Thus the soil 
of the assessment site is in dire need of fertilization measures with a complete (balanced) dose of fertilizer. According to Anonymous (2008), balanced fertilization is the addition of fertilizer into the soil with the amount and type of nutrients that are in accordance with the level of soil fertility and nutrient requirements by plants to increase production and quality of agricultural commodities.

Table 1 also shows that the use of Complete NPK fertilization with full measurements Treatment) gave significantly higher plant growth compared to without fertilization (B0 Treatment), without $\mathrm{N}$ fertilizer (B4 Treatment), without P fertilizer (B3 Treatment), and without $\mathrm{K}$ fertilizer (B2 Treatment). The treatment without $\mathrm{N}$ fertilizer (B4 Treatment) gives lower plant growth compared to the treatment with $\mathrm{N}$ fertilizer (B1 Treatment, B2 Treatment, and B3 Treatment). This shows that $\mathrm{N}$ fertilizer plays a role for plant vegetative growth. According to Anonymous (2008), nitrogen is needed for the formation or growth of vegetative parts of plants, such as leaves, stems and roots.

According to Rivera-Ferre et al. (2012), maintenance of soil fertility by applying fertilizers is an important management strategy to ensure continuity of plant growth, supports good soil conditions for growing crops. Likewise, land preparation greatly affects plant growth and yield. Ahmed \& Chowdhury (2006) reported that the soil cultivation locally using hoes and similar tools as a general methods reduce the drought effects and are useful for holding rainwater that plants can use for their growth.

\section{Components Yield of Yam's Local Tuber}

The results of the statistical analysis (Table 2) show that the tillage system only has a significant effect on the tuber weight of the crop, whereas fertilization has a real effect on all components of the yield of the tuber except for the tuber diameter. Whereas the interaction between tillage and fertilization systems did not have a real influence on the yield components of the yam's local tuber. Furthermore, Table 2 shows the intensive tillage system followed by making lengthwise mounds (A4 Treatment) giving a higher total number of tubers, a longer tuber length, a larger tuber diameter, a smaller percentage of small tubers, and a real planter tuber weight heavier than the minimum tillage system followed by making single mound. Intensive tillage followed by making lengthwise mound is an appropriate tillage system for creating friable and aeration conditions become good so that root growth and tuber formation go well causing the plant tuber weight to increase. This situation is in line with the objectives of land management namely; (a) loosening the soil to make it easier for roots to enter the soil, (2) improving soil aeration; (c) repair soil organisms; (d) controlling weeds; (e) add organic matter like humus and fertilizer into the soil; and (f) kill insects, especially eggs, larvae and their breeding grounds (Sinukaban 1987; Daywin 1984; Hillel 1980; Smith \& Wilkes 1977). 
Table 2. Tillage System and Fertilization for Increase Yield Component of Yam's Local Tuber at Makariki Experimental Garden, Central Moluccas

\begin{tabular}{|c|c|c|c|c|c|c|}
\hline Treatments & $\begin{array}{c}\text { Total } \\
\text { Number } \\
\text { Tuber }\end{array}$ & $\begin{array}{c}\text { Percentage } \\
\text { of Small } \\
\text { Tber }(\%)\end{array}$ & $\begin{array}{l}\text { Tuber } \\
\text { Lengh } \\
(\mathrm{cm})\end{array}$ & $\begin{array}{c}\text { Tuber } \\
\text { Diameter } \\
\left.(\mathrm{cm})^{*}\right)\end{array}$ & $\begin{array}{l}\text { Weigt of } \\
\text { Tuber per } \\
\text { Plant (gr) }\end{array}$ & $\begin{array}{c}\text { Tuber } \\
\text { Yield**) } \\
\text { (kg/harvest } \\
\text { plot) }\end{array}$ \\
\hline \multicolumn{7}{|l|}{ Main Plot = Tillage System } \\
\hline A1 $=$ MT + Single Mound & $31.67 \mathrm{a}$ & $38.95 \mathrm{a}$ & $10.66 \mathrm{a}$ & $5.97 \mathrm{a}$ & $1.536 \mathrm{~b}$ & $9.216 \mathrm{~b}$ \\
\hline $\mathrm{A} 2=\mathrm{MT}+$ Lenghtwise Mound & $38.20 \mathrm{a}$ & $30.08 \mathrm{a}$ & $11.83 \mathrm{a}$ & $6.45 \mathrm{a}$ & $1.692 \mathrm{ab}$ & $10.152 \mathrm{ab}$ \\
\hline A $3=$ IT + Single Mound & $43.73 \mathrm{a}$ & $35.65 \mathrm{a}$ & $11.41 \mathrm{a}$ & $6.34 \mathrm{a}$ & $1.770 \mathrm{ab}$ & $10.620 \mathrm{ab}$ \\
\hline A4 = IT + Lenghtwise Mound & $49.80 \mathrm{a}$ & $28.11 \mathrm{a}$ & $12.33 \mathrm{a}$ & $6.73 \mathrm{a}$ & $1.997 \mathrm{a}$ & $11.982 \mathrm{a}$ \\
\hline Average of Main Plot (MP) & 40.85 & 33.20 & 11.56 & 6.37 & 1.749 & 10.494 \\
\hline \multicolumn{7}{|l|}{ Sub Plot $=$ Fertilization } \\
\hline B0 $=$ Without Fertilization & $32.00 \mathrm{c}$ & $33.13 \mathrm{~b}$ & $10.83 \mathrm{~d}$ & $5.83 \mathrm{a}$ & $1.194 \mathrm{e}$ & $7.164 \mathrm{c}$ \\
\hline B1 = Complete NPK Fertilization & $52.50 \mathrm{a}$ & $38.50 \mathrm{a}$ & $13.16 \mathrm{a}$ & $7.15 \mathrm{a}$ & $2.186 \mathrm{a}$ & $13.116 \mathrm{a}$ \\
\hline B2 = NP Fertilization & $33.17 \mathrm{c}$ & $32.47 \mathrm{~b}$ & $10.92 \mathrm{~d}$ & $5.82 \mathrm{a}$ & $1.631 \mathrm{~d}$ & $9.786 \mathrm{~b}$ \\
\hline B3 = NK Fertilization & $43.33 \mathrm{~b}$ & $28.67 \mathrm{~b}$ & $11.72 \mathrm{c}$ & $6.68 \mathrm{a}$ & $1.958 \mathrm{~b}$ & $11.748 \mathrm{ab}$ \\
\hline B4 = PK Fertilization & $43.25 \mathrm{~b}$ & $33.22 \mathrm{~b}$ & $11.16 \mathrm{~d}$ & $6.39 \mathrm{a}$ & $1.773 \mathrm{c}$ & $10.638 \mathrm{~b}$ \\
\hline Average of Sub Plot (SP) & 40.85 & 33.20 & 11.56 & 6.37 & 1.749 & 10.494 \\
\hline Interaction MP x SP & ns & ns & ns & ns & ns & ns \\
\hline $\mathrm{CF}(\%) \mathrm{MP}$ & 25.92 & 36.09 & 19.76 & 12.91 & 13.41 & 12.99 \\
\hline SP & 16.38 & 35.14 & 8.77 & 18.85 & 15.93 & 15.23 \\
\hline
\end{tabular}

Remarks: The average number of lines followed by the same letter is not significantly different from accuracy level of $95 \%$ DMRT test.

ns : not significant

*) Average the tip, middle and base of the tuber

**) Yield from $2 \mathrm{~m} \mathrm{x} 3 \mathrm{~m}\left(6 \mathrm{~m}^{2}\right)$ harvest plots

Fertilization has a significant effect on all yield components except for the percentage of small tubers not significantly different (Table 2). Complete NPK fertilization with a dose of $135 \mathrm{~kg} \mathrm{~N}$ $+90 \mathrm{~kg} \mathrm{P} \mathrm{O}_{5}+135 \mathrm{~kg} \mathrm{~K} 2 \mathrm{O}$ per ha gives the number of tubers, tuber length, tuber diameter, and tuber weight weight significantly higher, and the percentage of small tubers tends to be lower than without fertilization (B0 Treatment), without $\mathrm{K}$ fertilizer (B2 Treatment), without $\mathrm{P}$ fertilizer (B3 Treatment), and without $\mathrm{N}$ fertilizer (B4 Treatment). This is because complete fertilization provides a balanced nutrient for plant growth and development so that the process of absorption and tranlocation of nutrient elements from roots to leaves runs smoothly. This situation supports the process of photosynthesis so that photosynthate from source to sink runs smoothly causing yield components (total tuber number, tuber length and diameter, tuber weight per plant) to increase and percentage of small tuber to decrease.

Table 2 also shows that without $\mathrm{N}$ fertilizer (B4 Treatment) and without $\mathrm{K}$ fertilizer (B2 Treatment) gives yield components (total tuber number, tuber length and diameter, and crop tuber weight) are reduced, while the percentage of small tuber tends to increase. This means that the elements nitrogen and potassium play a very important role in the growth and development of tubers. Lalopua et al. (1989) suggested that the yams plant (Dioscorea spp) is responsive to nitrogen and potassium, also requires an adequate supply of phosphorus. 
Yield of Yam's Local Tuber

The production of yam like every other crop is affected by factors varying from physical through economic to cultural factors. Obiokoro (2005) reported that climate, one of the physical factors, is the most crucial factor, which determines the nature of the natural vegetation, the characteristics of the soils, the crops that can be grown, and the type of farming that can be practiced in any region. Hence, any variation in climatic condition will have significant effects on crop productivity, especially yam yield. According to Oluwasusi \& Tijani (2013), yam production in Nigeria is among the most susceptible to the deleterious effects of climate change.

Yam's local tuber yields are converted from tuber yields per harvest plot $\left(6 \mathrm{~m}^{2}\right)$ and expressed as tuber yields per hectare. The interaction between tillage and fertilization systems was not significantly different from tuber yields per hectare, but single treatment of tillage system and fertilization gave a real difference (Table 3). Table 3 and Figure 1 shows the intensive tillage system followed by making lengthwise mounds (A4 Treatment) giving a higher yield tuber of Yam's local tuber is 19.97 t/ha, and not significant with A2 and A3 Treatments, but significant different with A1 Treatment.

Table 3. Tillage System and Fertilization for Increase Tuber Yield of Yam's Local Tuber at Makariki Experimental Garden, Central Moluccas

\section{Treatments} Tuber Yield*) (t/ha)

Main Plot = Tillage System

$\mathrm{A} 1=\mathrm{MT}+$ Single Mound

$\mathrm{A} 2=\mathrm{MT}+$ Lenghtwise Mound

$16.92 \mathrm{ab}$

A3 $=$ IT + Single Mound

$17.70 \mathrm{ab}$

A4 $=$ IT + Lenghtwise Mound

$19.97 \mathrm{a}$

Average of Main Plot (MP)

17.48

Sub Plot $=$ Fertilization

B0 $=$ Without Fertilization

$11.94 \mathrm{c}$

B1 = Complete NPK Fertilization

$21.86 \mathrm{a}$

$\mathrm{B} 2=$ NP Fertilization

$16.31 \mathrm{~b}$

B3 $=$ NK Fertilization

$19.58 \mathrm{ab}$

B4 = PK Fertilization

$17.73 \mathrm{~b}$

Average of Sub Plot (SP)

17.48

Interaction MP x SP

ns

$\mathrm{CF}(\%) \mathrm{MP}$

SP

15.23

Remarks: The average number of lines followed by the same letter is not significantly different from accuracy level of 95\% DMRT test.

ns : not significant

*) Converted from $2 \mathrm{~m}$ x $3 \mathrm{~m}\left(6 \mathrm{~m}^{2}\right)$ harvest plots 


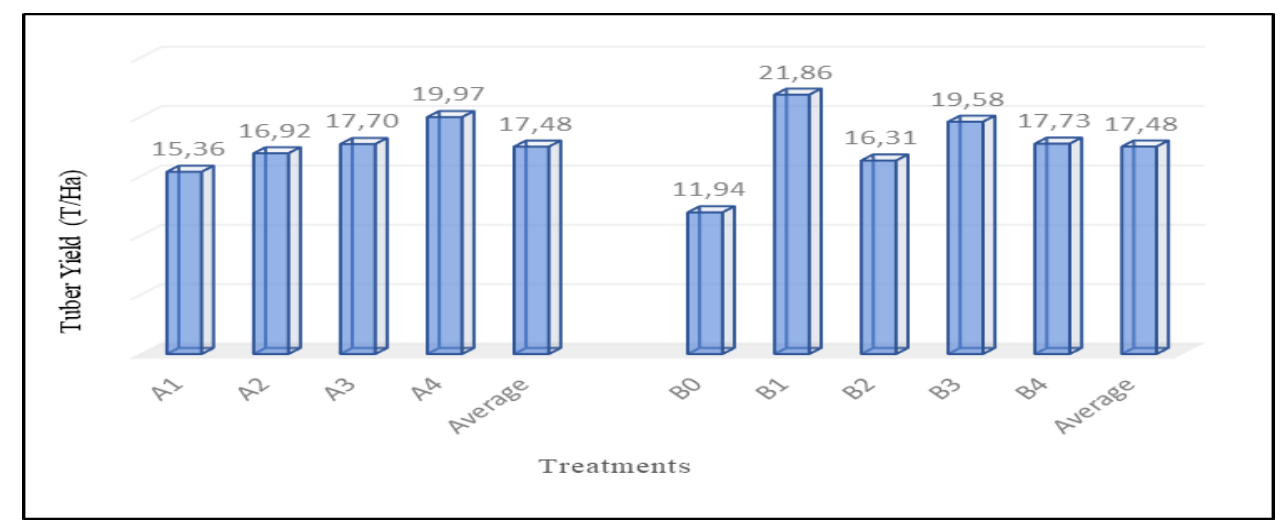

Figure 1. Tuber Yield (t/ha) of Tillage System and Fertilization

(Symbol of Treatments see Table 1)

Furthermore, Table 3 shows that the intensive tillage system followed by lengthwise mound (A4 Treatment) making yields the highest tuber yield per hectare and is significantly different compared to the minimum tillage system followed by single mound (A1 Treatment), but the A2 Treatment and A3 Treatment are not significantly different. Increased tuber yields per hectare in an intensive tillage system followed by making lengthwise mound (A4 Treatment) due to this system can loosen the soil and aeration well so that the creation of optimal growth media for root growth and development causes the plant to utilize growth factors especially water, nutrients, light, $\mathrm{O}_{2}, \mathrm{CO}_{2}$ properly and optimally. Plants that utilize growth factors optimally will grow perfectly, so that the yield component increases and the tuber yield also increases.

Plant production is influenced by many factors. In addition to the factors of farming techniques, it is also very much determined by climatic factors. Elijah et al. (2018) asserted that climate change is no longer a trivial issue, it is a reality that is seriously affecting the earth already, especially challenging agricultural productivity and food security in both developed and developing economies of the world and thus requires urgent attention. Similarly, Falola \& Achem (2017) posited that climate change is gradually attaining a catastrophic dimension given the associated impacts in the various key socio-economic sectors in recent time.

The growth component, yield component and tuber yield per hectare have a close relationship, which gives a very real positive correlation except the percentage of small tubers gives a negative correlation (Table 4). This illustrates that the higher plant growth, with the total number of tubers more followed by the size of the tubers (length and diameter) is increasing, and the weight of the tubers per plant heavier causing tuber yields per hectare to increase. In other words, the tuber yield per hectare is largely determined by the total tuber number $(\mathrm{r}=$ $0.7229 * *)$, plant height $(\mathrm{r}=0.6946 * *)$, tuber diameter $(\mathrm{r}=5049 * *)$, tuber weight per plant $(\mathrm{r}=0.4592 * *)$ and tuber length $(\mathrm{r}=0.4227 * *)$. 
Table 4. Simple Correlation Between Growth Components, Yield Components and Tuber Yields of Yam's Local Tuber at Makariki Experimental Garden, Central Moluccas

\begin{tabular}{lccccccc}
\hline Variable & $\begin{array}{c}\text { Plant } \\
\text { Height } \\
\text { (PH) }\end{array}$ & $\begin{array}{c}\text { Total } \\
\text { Tuber } \\
\text { Number } \\
(\text { TTN) }\end{array}$ & $\begin{array}{c}\text { Percentage } \\
\text { of Small } \\
\text { Tuber } \\
\text { (PST) }\end{array}$ & $\begin{array}{c}\text { Tuber } \\
\text { Lenght } \\
\text { (TL) }\end{array}$ & $\begin{array}{c}\text { Tuber } \\
\text { Diameter } \\
\text { (TD) }\end{array}$ & $\begin{array}{c}\text { Tuber } \\
\text { Weight/ } \\
\text { Plant } \\
\text { (TWP) }\end{array}$ & $\begin{array}{c}\text { Tuber } \\
\text { Yield/ } \\
\text { Hectare } \\
\text { (TYH) }\end{array}$ \\
\hline PH & 1.0000 & - & - & - & - & - & - \\
TTN & $0.5289 * *$ & 1.0000 & - & - & - & - & - \\
PST & 0.0117 & -0.1984 & 1.0000 & - & - & - & - \\
TL & $0.3131^{*}$ & $0.6382^{* *}$ & $-0.3514 * *$ & 1.0000 & - & - & - \\
TD & $0.3470 * *$ & $0.4200^{* *}$ & $-0.3522^{* *}$ & $0.3817 * *$ & 1.0000 & - & - \\
TWP & 0.2927 & $0.6114 * *$ & -0.2246 & $0.4497 * *$ & $0.3940 * *$ & 1.0000 & - \\
TYH & $0.6946 * *$ & $0.7229 * *$ & -0.0837 & $0.4227 * *$ & $0.5049 * *$ & $0.4592 * *$ & 1.0000 \\
\hline
\end{tabular}

Remarks: $\mathrm{n}=60$

$*=$ real correlation at $5 \%$ level

$* *=$ very real correlation at $1 \%$ level

The relationship between yield components and tuber yields per hectare occurs as a result of the treatment of tillage system and fertilization. The highest tuber yields achieved in this study were $19.97 \mathrm{t} / \mathrm{ha}$ (treatment of intensive tillage system followed by lengthwise mound, A4 Treatment) and $21.86 \mathrm{t} / \mathrm{ha}$ (Complete Fertilization, B1 Treatment) or an average of 17.48 $\mathrm{t} / \mathrm{ha}$, or $113 \%$ higher than the results of existing tubers $(8.20 \mathrm{t} / \mathrm{ha})$.

\section{Conclusions and Recommendations}

1. Tillage systems and fertilization have a significant effect on growth, yield and yield components of yam's local tuber, but the interaction both of them does not significantly.

2. The intensive tillage system followed by the lengthwise mound gives significantly higher growth and tuber yields (19.97 t/ha) compared to minimal tillage systems.

3. Use of a complete NPK single fertilizer with a dose of $135 \mathrm{~kg} \mathrm{~N}+90 \mathrm{~kg} \mathrm{P}_{2} \mathrm{O}_{5}+135 \mathrm{~kg}$ $\mathrm{K}_{2} \mathrm{O}$ per hectare gives the highest yield $(21.86 \mathrm{t} / \mathrm{ha})$ and is significantly different compared to other fertilization treatments, except for NK fertilization not significantly different (19.58 t/ha).

4. Nitrogen and Potassium Fertilizers have an important role in the growth and yield of yam's local tuber (Dioscorea esculenta).

5. Further research to determine the combination of the use of organic and inorganic fertilizers needs to be done to improve fertilizer efficiency.

\section{Acknowledgments}

Our sincere thanks and appreciation to Dr. Ir. Janes Berthy Alfons, M.Si for guidance in carrying out field activities so that this research can be carried out and completed. We also express our deep gratitude to all those who assisted with this research, from the beginning to the end of the activity. 


\section{References}

Ahmed, A. K., \& Chowdhury, E.H., (2006). Final Report of Study on Livelihood System Assessment, Vulnerable Groups Profiling and Livelihood Adaptation To Climate Hazard and Longterm Climate Change In Drought Prone Areas of NW Bangladesh (No. Final Report), Improved Adaptive Capacity to Climate Change for Sustainable Livelihood in the Agriculture Sector. Comprehensive Disaster Management Program (CDMP) BGD/01/004/99 DP/9/1. FAO, Department of Agricultural Extension, Bangladesh.

Akinola, A. A., Oke, J. T. O., Adesiyan, A. T., \& Famuyini, C. A. (2019). Climate Change and Economic Efficiency of Yam Farmers in Ekiti State, Nigeria. Invited Paper Presented at the 6th African Conference of Agricultural Economists, September 23-26, Abuja, Nigeria.

Alfons, J. B. (2002). Soil Management for Soybean-Based Farming on Dry Land: Crop Rotation, Soil and Alternative Fertilizer Systems. [Dissertation]. Bogor: Post-Graduate Program, IPB.

Anonymous. (2008). Nutritional Properties of Plants. http://ibra76.wordpress.com. Accessed August 8, 2010.

Babaleye, T. (2003). West Africa: Improving yam production technology. African News Bulletin, 463, 56-59.

Daywin, F. J. (1984). Mechanization of Agriculture and Agricultural Land Development. Paper Presented at the Upgrading of Agricultural Mechanization. Palembang 7 - 26 January 1984. Palembang: WUAE Project-UNSRI.

Elijah, S. T., Osuafor, O. O., \& Anarah, S. E. (2018). Effects of Climate Change on Yam Production in Cross River State, Nigeria. International Journal of Agriculture and Forestry, 8(2), 104-111.

Eprilianti, I. (2000). Potential of Dioscorea in Functional Food. Journal of Food Technology and Nutrition, 1(1), 29-38.

Falola, A., \& Achem, B. A. (2017). Perceptions on Climate Change and Adaptation Strategies Among Sweet Potato Farming Households in Kwara State North Central Nigeria. Ceylon Journal of Science, 46(3), 55-63. https://doi.org/10.4038/cjs.v46i3.7443

Gomez, K. A., \& Gomez, A. A. (1995). Statistical Procedures for Agriculture (2 ${ }^{\text {nd }}$ Edition). Sjamsuddin, E., Baharsjah, JS (Translator). Jakarta, University of Indonesia Publisher (Ul Press). Translation of Statistical Procedure for Agricultural Research.

Heyne, K. (1987). Indonesian Rerguna Plants. Volume I. The Jakarta Forestry Agency (Translator). Jakarta: Employee Cooperative Ministry of Forestry.

Hillel, D. (1980). Application of Soil Physics. New York: Acad. Press. https://doi.org/10.1016/B978-0-08-091870-9.50006-6

Irianto, B., Rieuwpassa, A. J., Bustaman, S., \& Waas, E. D. (1999). Characterization of Moluccas Agro Ecological Zones: Island Groups I and II. In. Wairisal, L.D., Irianto, B., 
Rahardljo, S., Dwiono, A. P., Latuconsina, J. R. (Editor). Proceedings of the Seminar on Results of Agricultural Assessment Fiscal Year 1997/1998. Book 11. Ambon, 15 July 16, 1998. Ambon Assessment Institute for Agricultural Technology, IAARD. p. 57-96.

Kang, B. T., \& Wilson, J. E. (1981). Effect of Mound Size and Fertilizer on White Guine Yam (Dioscorea rotundata) in Southern Nigeria. Plant and Soil: The Hague/Boston London, 61(3), 319-327. https://doi.org/10.1007/BF02182013

Lalopua, J. R., Wattimena, R. E., Waksen, A., \& Rahado, S. H. T. (1989). Tuber Crop Research at the Faculty of Agriculture, Pattimura University. In Minutes of Seminar on the Development of Potential Tubers Plants. Ambon, October, 31 1989. Ambon: The Faculty of Agriculture Unpatti Collaborates with USAID. p. 95-134.

Mahama, A. A. (1995). Technological Basis for Mechanized Seedbed Preparation for Yam in Bimbia Area, Ghana. Agricultural Mechanization in Asia, Africa and Latin America, 26(2), 21-23.

Mastur. (1994). Manipulation of Soil Physical Properties through Organic Fertilization and Tillage to Improve the Performance of Tillage Tools and Plants. [Thesis]. Bogor, Soil Science Study Program Post Graduate Program in Bogor Agricultural University.

Musa, Y. H. I., Onu, J., Vosanka, I. P., \& Anonguku, I. (2011). Production Efficiency of Yam in Zing Local Government Area of Taraba State, Nigeria. Journal of Horticulture and Forestry, 3(12), 372-378.

Nurida, N. L., Kusnadi, H., Vadari, T., \& Subagyono, K. (1999). Application of Tillage Techniques to Increase Soil Productivity in Typic Kanhapludults Jambi. p: 321-330. In. Agus, F., Las, I., Royan, A., Sukarman, Suryanto, Rochayati, S. \& Anda, M. (Editors). Proceedings of the National Seminar on Soil, Climate, and Fertilizer Resources. Lido-Bogor, December, 6-8 1999. Book II. Bogor: Center for Soil and Agro-Climate Research, IAARD, Ministry of Agriculture.

Nwingi, S. C. O. (1983). Optimal Time for Fertilization of Dioscorea rotundata. p. 136 - 137. In. Terry, E.R., Doku, E.V., Arene, O.B. \& Mahungu, N.M. (Eds.). Tropical Root Crops: Production and Uses in Africa. Proc. Trien Symp. Int. Soc. Trop. Root Crops, $2^{\text {nd }}$. Donala, Cameron, 14-19 August 1983.

Obiokoro, O. G. (2005). Agrometeorology, Onitsha: Dunkwu Publishers. pp. 24-30.

Oluwasusi, J. O., \& Tijani, S. A. (2013). Farmers Adaptation Strategies to the Effect of Climate Variation on Yam Production: A Case Study in Ekiti State, Nigeria. Agrosearch, 13(2), 20-31. https://doi.org/10.4314/agrosh.v13i2.3

Rieuwpassa, A. J., Irianto, B., Bustaman, S., \& Waas, E. D. (1999). Characterization of Moluccas Agro Ecological Zones: Island Groups IV, V, V1, VII and VIII. In. Wairisal, L.D., Irianto, B., Rahardjo, S., Dwiono, A. P., Latuconsina, J. R. (Editor). Proceedings of the Seminar on Results of Agricultural Assessment Results Piscal Year 1997/1998 Book II. Ambon, July, 15-16 1998. Ambon Assessment Institute for Agricultural Technology, IAARD. 
P. 97-116.

Rivera-Ferre, M. G., Di Masso, M., Miele, M., López-i-Gelats, F., Gallar, D., Vara, I., \& Cuellar, M. (2012). Understanding the Role of Local and Traditional Agricultural Knowledge in a Changing World Climate: The case of the Indo-Gangetic Plains. pp. 98.

Sianipar. H. (2015). http://germplasm and its conservation. wordpress.com. Downloaded on September 07, 2020.

Sinukaban, N. (1987). Conservation Tillage in Rice and Corn Farming. In. Utomo, I.H., Wiroatmodjo, J. (Editor). P. 25-35. Proceedings of the Seminar on Agriculture without Land Cultivation. Bogor: Bogor Agricultural University.

Smith, M. J., \& Wilkes, L. H. (1977). Farm Machinery and Equipment. New York: McGraw Hill Co.

\section{Copyright Disclaimer}

Copyright for this article is retained by the author(s), with first publication rights granted to the journal.

This is an open-access article distributed under the terms and conditions of the Creative Commons Attribution license (http://creativecommons.org/licenses/by/4.0/). 